\title{
HYDROCHEMICAL AND ECOLOGICAL QUALITY ASSESSMENT OF A MEDITERRANEAN RIVER SYSTEM
}

\author{
N.TH. SKOULIKIDIS* \\ K. GRITZALIS \\ TH. KOUVARDA
}

Received: 23/05/02

Accepted: 22/10/02

\author{
National Centre for Marine Research \\ Institute of Inland Waters \\ Agios Kosmas, Hellinikon, 16604 Athens, Greece
}

* to whom all correspondence should be addressed

\begin{abstract}
In order to explore the complex interrelations among the factors and processes that determine a rivers' hydrochemical and biological quality, statistical techniques were applied to a variety of hydrochemical, petrologic, biological, habitat, hydrological and morphologic data from 16 sites of the upper-part of the Aliakmon river. Catchment morphology and geology control both, aquatic and biological quality, the latter is mainly governed by substrate composition. The principal processes that control aquatic quality are: a) baseflow contribution in river flow b) in-stream biological activity and pollution c) weathering of mafic silicates. Using a Nutrient Pollution Metric (which has been developed), a hydrochemical quality classification has been performed. Furthermore, a methodology, based on benthic macroinvertebrates and aquatic quality, for the assessment of the ecological quality of running waters is presented.
\end{abstract}

KEYWORDS: biological, hydrochemical and ecological quality, benthic macroinvertebtares, biotic metric, nutrient pollution metric, hydrochemical quality and classification

\section{INTRODUCTION}

A river is an open system with strong interactions with its drainage basin. Various abiotic and biotic processes, such as tectonic dynamics, weathering, erosion and sedimentation, evaporation, biological activity, adsorption and desorption, flushing etc. as well as human interference, interact within the watershed, the river floodplains, the riparian zone and the water body, determining its aquatic composition and ecological character (Petts and Calow, 1996).

Thousands of years ago humans started influencing the water bodies. The biological, physicochemical and hydro-morphological characteristics of a large number of them have deteriorated to such an extent, that there is a wide consensus for the need to recover, at least partially, their original characteristics. The EU seeks through the Water Framework Directive (WFD, 2000/60 EU) to apply a methodology, deadline and recovery level to this process. The WFD introduces the term "ecological status" to the assessment of environmental quality, which is determined by chemical, biological and hydromorphological elements. Member States are obliged to characterise and classify their water bodies according to typological characteristics, establish criteria for type-specific reference conditions, identify pressures and assess impacts and, finally, classify water bodies according to their ecological status into five qual- 
ity categories (high, good, moderate, poor, bad). One of the principal objectives of the WFD is to achieve at least "good status" for all European surface water until the year 2015 the latest. The classification of the ecological status of a particular water body will be done by means of comparison between the observed values of the quality elements and the reference (background) values of the particular water body. Although many definitions of the reference status exist, within the REFCOND project ("Development of a protocol for identification of reference conditions, and boundaries between high, good and moderate status in lakes and watercourses"), the term is used to describe expected background conditions with no or minimal anthropogenic stress.

European Mediterranean catchments, especially those in Greece, are marked by high spatial differences in morphologic, climatic, hydrographic, petrographic and vegetative features and variability in pollution impact (Skoulikidis, 1991). As a result, river and stream habitat, hydrochemical regime and biocommunity structure, vary considerably along their courses. In addition, research on ecological quality assessment is limited and geographically restricted and classification systems are absent. Hence, the assessment of the ecological quality of Greek rivers is a complex task and needs a special approach, since an optimal "ecological quality assessment" can only be achieved through regional adaptations (Tolkamp, 1984).

The aim of the article is to reveal the factors and biogeochemical processes that control aquatic and biotic quality of the upper part of Aliakmon, a river system with variable physiographic and anthropogenic characteristics. Following the requirements of the WFD, a second task is to present a first approach towards a chemical classification of Greek running waters. It finally presents an ecological quality assessment methodology, based on benthic macroinvertebrates and aquatic pollution.

\section{STUDY AREA}

Aliakmon River originates in Vernon mountain, north - western Greece. The upper part of the river is limited downstream by the artificial lake Polyphyto (Fig. 1), which receives an average annual water amount of $1.5 \mathrm{~km}^{3}$. The upper part of the catchment area, which lies almost entirely above $500 \mathrm{~m}$ and exhibits a continental climate, covers a surface of ca. $5,800 \mathrm{~km}^{2}$. It mainly con- sists of recent sediments (quaternary-neogene) and molasse, which cover $79 \%$ of the catchment (Table 1). The main point pollution sources (municipal waste waters mainly originating from the towns Argos Orestiko, Neapolis, Grevena and the surrounding villages, as well as the outflow of Kastoria lake) affecting surface water are distributed in the central lowlands of the drainage basin, mainly along the mainstream, whereas the surrounding mountainous areas are, more or less, undisturbed. In addition, the lowland areas are intensively cultivated. The examined sub-catchments present variable morphological and geological characteristics and river bed shows distinct substrate and habitat features.

\section{METHODOLOGY}

Sixteen sampling stations were selected along the flow of Aliakmon River and its tributaries ( 7 on the mainstream and 9 on tributaries) (Fig. 1). The selection criteria were petrologic, morphologic, habitat related, the distribution of human activities and pollution sources and the flow regime. Sampling took place in July 1996 and March 1997, which represent two characteristic seasons in Greece (warm - dry and cold - humid, respectively). At each sampling station, the flow velocity was measured with a General Oceanics flow meter. Physicochemical parameters (temperature, dissolved oxygen, $\mathrm{pH}$, conductivity, turbidity) were measured in-situ with a portable water quality meter (Horiba Water Checker). Water samples were collected and stored in $500 \mathrm{ml}$ plastic bottles and were transferred in the laboratory under low temperature. The samples were then filtered through $0.45 \mu$ filters. Alkalinity, Total Hardness, $\mathrm{Ca}^{2+}$ and $\mathrm{Mg}^{2+}$ were measured by titration, using a digital titration system (ABU901 Radiometer), while P-PO- ${ }_{4}^{-3}, \mathrm{~N}_{-} \mathrm{NO}_{3}^{-}, \mathrm{N}-\mathrm{NO}_{2}^{-}, \mathrm{N}-\mathrm{NH}_{4}^{+}, \mathrm{SO}_{4}^{2-}, \mathrm{Cl}^{-}$, $\mathrm{SiO}_{2}$ and $\mathrm{K}^{+}$, were analysed by the Hack procedures.

Invertebrate fauna was collected by means of a special hand net (diameter $500 \mu \mathrm{m}$ ), using the kick-sweep method (Armitage et al., 1983). The surface of the sampling area was $1 \mathrm{~m}^{2}$. All habitat types of each station, including plants, soft and hard bottom strata were present. However, not all habitat types were covered, due to difficulty in accessing some of them. Samples were preserved in a $70 \%$ ethanol solution. In the laboratory, the organisms were identified down to the lowest tax- 


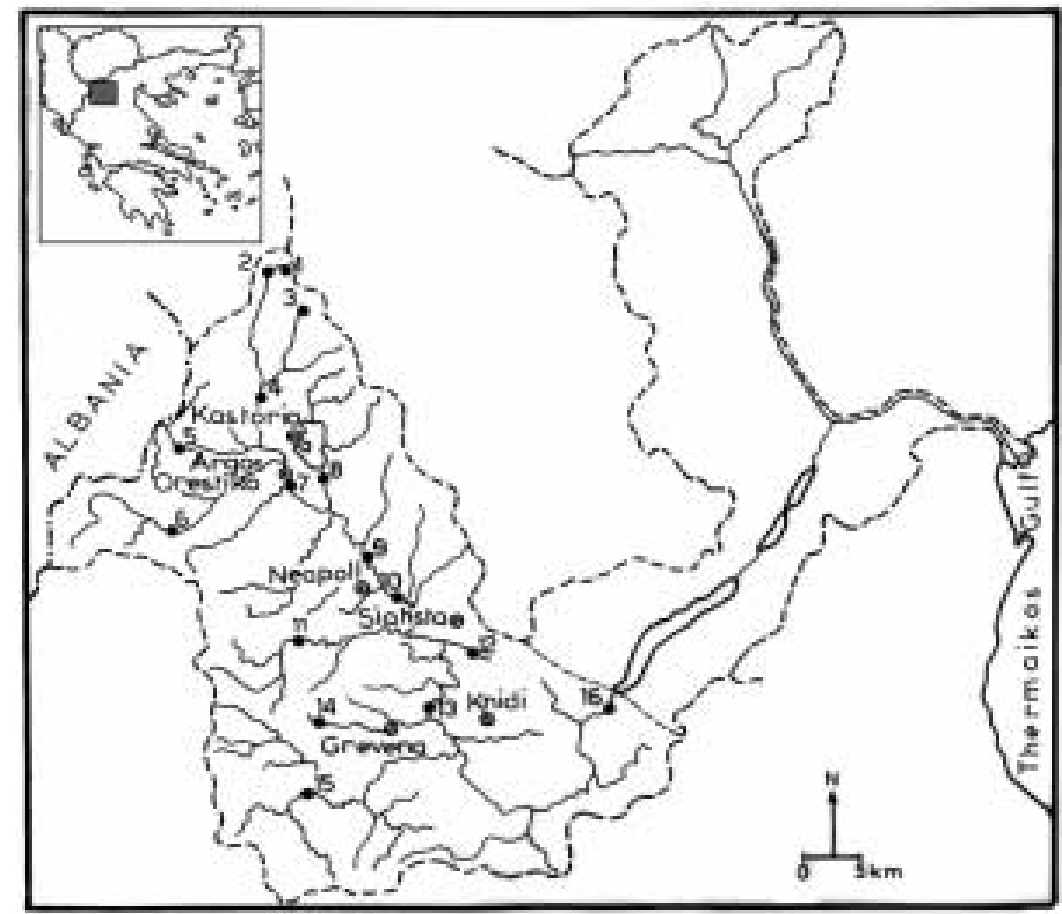

catchment and sub-catchment (study) area

Figure 1. The upper-Aliakmon river drainage and sample stations (italic symbols indicate the tributaries) 1. Pisoderi, 2. Andartiko, 3. Melas, 4. Gavros, 5. Vrochopotamos, 6. “Aliakmon”, 7. Argos OrestikoAmoudara bridge, 8. Kastoria-lake overflow, 9. Neapolis-Argos Orestiko bridge, 10. Neapolis-Siatista bridge, 11. Pramoritsa, 12. Sarandaporos, 13. Grevena-Knidi bridge, 14. Grevenitis, 15. Venetikos, 16. Agios Ilarion

Table 1. Selected typological characteristics of Aliakmon river

\begin{tabular}{|lll|}
\hline Total catchment & $\mathrm{km}^{2}$ & 9,200 \\
\hline Catchment of study area & $\mathrm{km}^{2}$ & 5,800 \\
\hline Total discharge & $\mathrm{km}^{3} \mathrm{year}^{-1}$ & 3.13 \\
\hline Discharge of study area & $\mathrm{km}^{3} \mathrm{year}^{-1}$ & 1.50 \\
\hline Total length & $\mathrm{km}^{-1}$ & 320 \\
\hline Natural hydrological type & & snow-rain $\mathrm{b}^{1}$ \\
\hline Geology of study area & $\mathrm{km}^{2}(\%)$ & \\
Carbonates & & $324(5.6)$ \\
Acid silicates & & $510(8.8)$ \\
Mafic silicates & $384(6.6)$ \\
Flysch - Molasse & & $1,844(31.8)$ \\
Neogene - Quaternary & & $2,739(47.2)$ \\
\hline Hydrochemical type & & hard \\
& & high magnesium concentration \\
\hline
\end{tabular}

${ }^{1}$ Max discharge in spring, second peak in winter (Malikopoulos, 1957)

${ }^{2}$ Hardness classification (Hem, 1970) 
Table 2. PCA results on pollution parameters

\begin{tabular}{|cccc|}
\hline Varariance \% & 70 & Components & 4 \\
\hline & & PC2 & PC3 \\
\hline Variable & PC1 & 0.15113 & 0.18991 \\
\hline $\mathrm{NO}_{3}^{-}$ & 0.5826 & 0.98241 & 0.07849 \\
$\mathrm{NO}_{2}^{-}$ & -0.11612 & -0.05007 & 0.58763 \\
$\mathrm{NH}_{4}^{+}$ & 0.5756 & 0.09761 & -0.7826 \\
$\mathrm{PO}_{4}^{3-}$ & 0.56194 & Scores & \\
\hline & & PC2 & PC3 \\
\hline Station & PC1 & 0.77058 & -0.22951 \\
1 & 0.18801 & 0.61792 & -0.15989 \\
2 & 0.17481 & 1.06014 & -0.18213 \\
3 & 0.18539 & 1.00051 & -0.11484 \\
4 & 0.49602 & 1.21695 & 0.03692 \\
5 & 0.74516 & 1.20606 & 0.21036 \\
6 & 0.65786 & 1.8019 & -2.40521 \\
7 & 3.04609 & 1.59665 & 5.47206 \\
8 & 15.35283 & 1.75303 & 0.1893 \\
9 & 1.32596 & 1.03515 & -0.38058 \\
10 & 0.79452 & 0.79147 & -0.32595 \\
11 & 0.4418 & 0.78624 & -0.14619 \\
12 & 0.28821 & 1.17347 & -0.18009 \\
13 & 0.70393 & 1.90126 & -0.17655 \\
14 & 0.57083 & 1.2154 & -0.28466 \\
15 & 0.20123 & 0.97052 & -0.14816 \\
16 & 0.49164 & & \\
\hline
\end{tabular}

onomic group by means of dichotomic keys.

Substrate composition (\% of bedrock-boulders, pebbles-cobbles, sand and silt-clay fraction), was assessed in-situ.

In order to assess the influence of chemical weathering, on the aquatic quality of each sampling station, the corresponding catchment area was determined and the surface of each geochemical important rock type was measured. Next, the percentage contribution of each rock type was easily calculated.

A Nutrient Pollution Metric (NPM) was developed using a Principal Component Analysis (PCA), which was carried out on the average concentrations of pollution parameters $\left(\mathrm{NO}_{3}^{-}, \mathrm{NO}_{2}^{-}\right.$, $\mathrm{NH}_{4}^{+}, \mathrm{PO}_{4}^{3-}$ ) examined in both sampling periods at the 16 sampling sites.

For the biological quality assessment a set of existing biological quality metrics was applied, correlated against NPM. Best correlation was provided by the Spanish Biological Monitoring Working Party (Spanish-BMWP) score system (Alba-Tercedor and Sanchez-Ortega, 1988).
Next, the Spanish-BMWP was divided by 10 (maximum score). A site score was obtained by summing the individual scores of all families present. Finally, the Spanish Average Score Per Taxon (ASPT) index was calculated, by dividing the site score by the total number of scoring taxa. The biotic metric (BM) formula is the following:

$B M_{i}=\frac{A S T P_{i}}{10}=\sum_{i=1}^{n} \frac{B M W P_{i}}{10 \times b_{i}}$

Where: i, site number

$b$, total number of taxa

Table 3 contains the BM values for each sampling site.

A Rank Correlation (RC) was applied on all examined abiotic variables, NPM and BM, in order to assess the influence of abiotic factors and pollution on macroinvertebrates presence and abundance.

Furthermore, a PCA was carried out on the same data in order to examine the factors controlling the chemical and biological quality of the river. A 
Table 3. Physical characteristics, seasonal averages of the examined parameters and the calculated indices in the upper Aliakmon River system (for numbering 1-16, see Fig. 1)

\begin{tabular}{|c|c|c|c|c|c|c|c|c|c|c|c|c|c|c|c|c|c|}
\hline \multirow[b]{2}{*}{ Parameter } & \multicolumn{17}{|c|}{ Sampling Stations } \\
\hline & Units & 1 & 2 & 3 & 4 & 5 & 6 & 7 & 8 & 9 & 10 & 11 & 12 & 13 & 14 & 15 & 16 \\
\hline $\mathrm{HCO}_{3}$ & mval $~^{-1}$ & 0.98 & 0.98 & 1.12 & 2.27 & 4.35 & 3.28 & 3.75 & 6.7 & 3.98 & 3.87 & 4.19 & 5.37 & 4.08 & 6.66 & 3.84 & 4.17 \\
\hline $\mathrm{CO}_{3}^{-}$ & mval $^{-1}$ & 0.06 & 0 & 0 & 0.235 & 0 & 0.125 & 0.72 & 0 & 0.215 & 0.27 & 0.093 & 0.478 & 0 & 0 & 0.223 & 0.23 \\
\hline $\mathrm{Ca}^{2+}$ & $\mathrm{mg} \mathrm{l}^{-1}$ & 5.03 & 5.6 & 5.33 & 32.55 & 59.7 & 48.7 & 64.5 & 68.7 & 66.1 & 66.1 & 55.3 & 52.5 & 43.3 & 50.8 & 51.7 & 38.5 \\
\hline $\mathrm{Mg}^{2+}$ & $\mathrm{mg} \mathrm{l}^{-1}$ & 6.6 & 7.3 & 4.2 & 5.19 & 17.67 & 13.4 & 14.3 & 21.06 & 15.36 & 16.63 & 18.33 & 28.5 & 21.4 & 28.7 & 17.9 & 31.3 \\
\hline $\mathrm{SO}_{4}^{2-}$ & $\mathrm{mg} \mathrm{I}^{-1}$ & 4 & 7.5 & 4.5 & 9 & 51 & 28 & 27.5 & 41 & 28 & 27 & 27.5 & 15.5 & 32.5 & 56.5 & 25 & 28.5 \\
\hline $\mathrm{Cl}$ & $\mathrm{mgl}^{-1}$ & 4 & 4.1 & 0.8 & 1.4 & 3.1 & 1.89 & 3.05 & 21.5 & 2.5 & 4.4 & 5.5 & 2.1 & 4.7 & 13 & 5.2 & 5.6 \\
\hline $\mathrm{O}_{2}$ & $\%$ & 82.3 & 83.7 & 85 & 90.6 & 90.9 & 110.9 & 121.2 & 28.3 & 109.8 & \begin{tabular}{|l|}
110.7 \\
\end{tabular} & 85.1 & 123.6 & 114.5 & 62.3 & 93.2 & 102 \\
\hline $\mathrm{pH}$ & & 7.95 & 7.96 & 8.1 & 8.37 & 8.46 & 8.79 & 8.75 & 7.81 & 8.58 & 8.58 & 8.43 & 8.91 & 8.71 & 8.62 & 8.59 & 8.79 \\
\hline Conduct. & $\mathrm{mS} \mathrm{cm}^{-1}$ & 0.05 & 0.06 & 0.056 & 0.222 & 0.446 & 0.32 & 0.387 & 0.838 & 0.414 & 0.411 & 0.413 & 0.498 & 0.413 & 0.787 & 0.355 & 0.452 \\
\hline Temper. & ${ }^{\circ} \mathrm{C}$ & 10.1 & 9.85 & 11.05 & 10.7 & 11.05 & 16.5 & 13.6 & 16.7 & 14.9 & 16.1 & 14.05 & 17.75 & 16.9 & 13.1 & 17.05 & 15.3 \\
\hline $\mathrm{SiO}^{2}$ & $\mathrm{mg}^{-1}$ & 11.2 & 10.5 & 12.8 & 6.95 & 7.4 & 11.5 & 6.1 & 16.5 & 6.5 & 8 & 7.3 & 26.2 & 8.2 & 20.3 & 7.8 & 11.4 \\
\hline $\mathrm{N}-\mathrm{NO}_{3}$ & $\mathrm{mg} \mathrm{l}^{-1}$ & 0.12 & 0.13 & 0.15 & 1 & 1.8 & 0.46 & 3 & 10.85 & 2.8 & 0.99 & 0.165 & 0.34 & 1.15 & 1.17 & 0.13 & 0.67 \\
\hline $\mathrm{N}-\mathrm{NO}_{2}$ & $\mathrm{mg}^{-1}$ & 0.005 & 0.004 & 0.007 & 0.006 & 0.007 & 0.008 & 0.008 & 0.005 & 0.01 & 0.006 & 0.005 & 0.005 & 0.007 & 0.012 & 0.008 & 0.006 \\
\hline $\mathrm{N}-\mathrm{NH}_{4}^{+}$ & $\mathrm{mg}^{-1}$ & 0.005 & 0.015 & 0.02 & 0.002 & 0.001 & 0.285 & 0.002 & 6.12 & 0.11 & 0.05 & 0.075 & 0.03 & 0.045 & 0.004 & 0.003 & 0.055 \\
\hline P-PO & $\mathrm{mg} \mathrm{l}^{-1}$ & 0.07 & 0.055 & 0.07 & 0.07 & 0.06 & 0.075 & 0.65 & 0.985 & 0.095 & 0.145 & 0.115 & \begin{tabular}{|l|l|} 
& 0.065 \\
\end{tabular} & 0.105 & 0.105 & 0.09 & 0.085 \\
\hline $\mathrm{N} / \mathrm{P}$ & & 4,1 & 6,0 & 5,6 & 31,9 & 66,7 & 22,2 & 10,2 & 38,1 & 68,0 & 16,0 & 4,7 & 12,8 & 25,3 & 25,0 & 3,5 & 19,0 \\
\hline $\mathrm{N} / \mathrm{P}$ & weight & 1,9 & 2,7 & 2,5 & 14,4 & 30,1 & 10,0 & 4,6 & 17,2 & 30,7 & 7,2 & 2,1 & 5,8 & 11,4 & 11,3 & 1,6 & 8,6 \\
\hline $\mathrm{TDS}^{1}$ & $\mathrm{mg}^{-1}$ & 31.2 & 36.9 & 31.4 & 45 & 49.2 & 92.6 & 39.1 & 99.7 & 47.7 & 11.1 & 11.4 & 35.2 & 9.1 & \begin{tabular}{|l|}
16.4 \\
\end{tabular} & 29.9 & 49.6 \\
\hline $\mathrm{NPM}^{2}$ & & 0.32 & 0.28 & 0.39 & 0.60 & 0.82 & 0.76 & 2.58 & 11.16 & 1.37 & 0.81 & 0.50 & 0.40 & 0.78 & 0.87 & 0.44 & 0.59 \\
\hline $\mathrm{BM}^{3}$ & & 0.82 & 0.70 & 0.76 & 0.76 & 0.60 & 0.59 & 0.62 & 0.33 & 0.67 & 0.57 & 0.68 & 0.77 & 0.83 & 0.53 & 1.00 & 0.72 \\
\hline Acid R.4 & $\%$ & 100 & 90 & 60 & 60.1 & 0 & 0 & 10.5 & 0 & 9.9 & 10.3 & 0 & 0 & 8.9 & 0 & 0 & 8 \\
\hline Carb. R. & $\%$ & 0 & 0 & 0 & 8.3 & 0 & 100 & 4.3 & 0 & 4.7 & 4.6 & 0 & 0 & 5.4 & 0 & 10 & 5.5 \\
\hline Molasse & $\%$ & 0 & 0 & 0 & 0 & 75 & 0 & 12.8 & 0 & 23.8 & 25 & 100 & 0 & 28.9 & 100 & 90 & 34.5 \\
\hline$N \cdot Q^{6}$ & $\%$ & 0 & 10 & 25 & 17.3 & 25 & 0 & 71.6 & 100 & 61 & 59.5 & 0 & 0 & 55 & 0 & 0 & 45 \\
\hline Mafic R. & $\%$ & 0 & 0 & 15 & 4.3 & 0 & 0 & 0.8 & 0 & 0.6 & 0.6 & 0 & 100 & 1.8 & 0 & 0 & 7 \\
\hline Flow & $\mathrm{m} \mathrm{s}^{-1}$ & 1 & 2.65 & 0.18 & 0.8 & 0.6 & 0.9 & 2.48 & 0.23 & 1.3 & 1.3 & 0.05 & 0.15 & 2.4 & 0.1 & 0.35 & 0.75 \\
\hline Elevation & $\mathrm{m}$ & 1380 & 1060 & 1080 & 650 & 720 & 780 & 615 & 630 & 570 & 550 & 640 & 680 & 460 & 720 & 700 & 310 \\
\hline Slope & $\%$ & 8.3 & 5 & 8 & 0.3 & 1 & 0.8 & 0.85 & 0.1 & 0.6 & 0.7 & 2 & 5 & 0.95 & 4 & 1.5 & 0.36 \\
\hline$B \cdot b^{7}$ & $\%$ & 50 & 50 & 70 & 25 & 35 & 10 & 30 & 0 & 0 & 0 & 80 & 35 & 0 & 35 & 70 & 30 \\
\hline$P-c^{8}$ & $\%$ & 32 & 25 & 0 & 40 & 0 & 15 & 50 & 0 & 25 & 85 & 5 & 55 & 75 & 0 & 9 & 50 \\
\hline Sand & $\%$ & 10 & 20 & 20 & 30 & 0 & 0 & 7.5 & 0 & 20 & 10 & 4 & 8 & 14 & 5 & 5 & 5 \\
\hline Silt-clay & $\%$ & 8 & 5 & 10 & 5 & 65 & 75 & 12.5 & 100 & 55 & 5 & 11 & 2 & 11 & 60 & 16 & 15 \\
\hline
\end{tabular}

${ }^{1}$ Total Dissolved Solids, ${ }^{2}$ Nutrient Pollution Metric, ${ }^{3}$ Biotic Metric, ${ }^{4}$ rocks, ${ }^{5}$ Carbonate rocks, ${ }^{6}$ Neogene-Quaternary, ${ }^{7}$ Bedrock-boulders, ${ }^{8}$ Pebbles-cobbles

combination of the Italian and French chemical quality classes, as well as the NPM have been applied, for the hydrochemical classification of the river. Finally, the BM and NPM were used for the ecological quality assessment of the river.

\section{RESULTS}

According to Table 2, that presents the PCA results on pollution parameters, three Principal
Components represent $99 \%$ of the total variance. For each station, $\mathrm{PC} 1$ and $\mathrm{PC} 2$ values (PC3 was excluded because of its very low proportion) were multiplied with their corresponding PC Proportion and the results were added forming the NPM.

$\mathrm{NPMi}=\mathrm{PC}_{\mathrm{i}}^{*} \mathrm{PC} 1 \%+\mathrm{PC}_{\mathrm{i}}{ }^{*} \mathrm{PC} 2 \%$

where: i, site number. 
The advantage of NPM, compared to a metric resulting from the weighted average of nutrient concentrations, is that it is independent from extreme values.

Table 3 presents the river's physical features, the average results of the physicochemical and hydrochemical parameters and the NPM and BM.

Table 4 presents the results of the PCA carried out on all data obtained while Annex I presents the results of the Rank Correlation (RC).

\section{DISUSSION}

\subsection{Factors and processes controlling hydrochemical and biological quality}

According to the results of PCA and RC, the following information could be obtained:

The strong relationship between solute concentration and morphology is attributed to hydrogeological factors; lowland sites are more affected by baseflow, which is rich in solutes (including nutrients), than highland ones. Hence, Factor 1 ( $38.1 \%$ of the total variance), represents the contribution of baseflow in river flow.

The correlations between BM and NPM with conductivity, as well as with the partition of neogenequaternary sediments, which increases in the lowland catchments, is due to the simultaneous downstream enrichment of river water with ions and pollutants (Skoulikidis, 1993). In general, lowland and flat sites, which are situated in subbasins with limited presence or lack in acid rocks and high percentage of recent sediments (neogene-quaternary), are dominated by low grain size (silty-clayey) deposits and show high water temperatures. These sites are highly mineralised and show a relative degradation in aquatic and biological quality.

Factor 2 (20.6\% of the total variance) corresponds to biological activity and pollution. It also clearly presents the correlation between NPM and BM.

In sites with relatively low nutrient concentrations and high water temperatures and substrate mainly formed by pebbles/cobbles, photosynthetic processes prevail, which causes high oxygen and $\mathrm{pH}$ values and partly appearance of carbonate ions. These sites show high biological quality (high BM). In contrast, polluted sites (high NPM - low BM) are marked by decomposition processes (respiration). These sites are situated in the lowlands and are characterised by silty-clayey sub- strate and high chloride concentrations, which are related to municipal waste water discharges.

Examples of prevailing photosynthesis (oxygen supersaturation, elevated $\mathrm{pH}$ and occurrence of $\mathrm{CO}_{3}^{2-}$ ) and respiration (low dissolved oxygen, low $\mathrm{pH}$, high $\mathrm{HCO}_{3}^{-}$concentration) are the lowland Aliakmon main stem sites (st. 10, 13 and 16) and the Kastoria-Lake outflow (st. 8) respectively. Intense respiration processes in Kastoria-Lake outflow result in oxygen depletion in summer $\left(0.3 \mathrm{mg} \mathrm{l}^{-1}\right)$. Finally, the clear upland river parts (st. 1, 2, 3) show oxygen undersaturation possibly because of the influence of altitude on the equilibrium concentration (Knoben et al., 1995).

$\mathrm{N} / \mathrm{P}$ ratios indicate the limiting factor for photosynthesis. It is assumed that for a N/P ratio (in weight) $>10$, phosphorus is the limiting factor and for $\mathrm{N} / \mathrm{P}$ ratio $<5$, nitrogen is limiting (e.g. Cadorso et al., 2001). At the clean upstream Aliakmon main stem and tributary sites (st. 1, 2 and 3,11 and 15 respectively), photosynthesis is nitrogen limited. The polluted site 7 , which is affected by - rich in phosphorus - municipal and slaughter wastes of the town Argos Orestiko and the surrounding villages (Maniaki, Nestorio, Ammudara), also belongs to this group. At Aliakmon's main stem sites 4, 9, 13, the tributary sites 5, 14 and the heavily polluted Kastoria-Lake outflow (st. 8), photosynthetic activity is limited by phosphorus.

Substrate and habitat composition primarily determines the type of aquatic communities (Knoben et al., 1995). Substrates with high pebble-cobble percentage show high biological quality, whereas silty-clayey ones present low biological quality. These relationships are not only due to habitat preferences of macroinvertebrates (Ward, 1992), but also to the fact that silty-clayey substrates are situated at lowland river parts, that are more polluted.

Factor 3 (12.4\% of the total variance) reflects the weathering of mafic minerals. Streams with high participation of mafic rocks and/or molasse in their subcatchments, which flow slowly through bedrock outcrops and boulders, are marked by high concentrations of magnesium and/or silicate (st. $5,11,12,14,16)$. This is due to the weathering of olivine and serpentine minerals of mafic rocks and molasse, which obviously contains mafic rock debris. 
Table 4. PCA on the physical characteristics, seasonal averages of the examined parameters and the calculated metrics in the upper Aliakmon River system (for numbering 1-16 see Fig. 1, for abbreviations see Table 3, bold numbers: maximum scores, italic numbers: high scores)

\begin{tabular}{|c|c|c|c|}
\hline Variance $\%$ & 38,1 & 20,6 & 12,4 \\
\hline Factor & $\begin{array}{c}\text { Baseflow } \\
\text { contribution }\end{array}$ & $\begin{array}{l}\text { 1. Biological Activity } \\
\text { 2. Pollution }\end{array}$ & $\begin{array}{c}\text { Weathering } \\
\text { of mafic minerals }\end{array}$ \\
\hline $\mathrm{BM}$ & 0,16017 & 0,27208 & 0,07146 \\
\hline NPM & $-0,19988$ & $-0,24806$ & 0,14505 \\
\hline $\mathrm{HCO}_{3}^{-}$ & $-0,26791$ & 0,0436 & $-0,15911$ \\
\hline $\mathrm{CO}_{3}^{-}$ & $-0,04486$ & 0,20712 & 0,10996 \\
\hline $\mathrm{Ca}_{2}^{+}$ & $-0,24813$ & 0,1098 & $-0,01885$ \\
\hline $\mathrm{Mg}_{2}^{+}$ & $-0,21085$ & 0,15671 & $-0,19354$ \\
\hline $\mathrm{SO}_{4}^{2-}$ & $-0,23771$ & 0,03718 & $-0,17077$ \\
\hline $\mathrm{Cl}^{-}$ & $-0,21900$ & $-0,19895$ & $-0,05401$ \\
\hline $\mathrm{O}_{2}$ & $-0,05288$ & 0,37135 & 0,07235 \\
\hline $\mathrm{pH}$ & $-0,19669$ & 0,2643 & $-0,01168$ \\
\hline Conduct. & $-0,27348$ & $-0,00182$ & $-0,13159$ \\
\hline Temper. & $-0,22549$ & 0,18807 & $-0,01627$ \\
\hline $\mathrm{SiO}_{2}$ & $-0,1172$ & $-0,04087$ & $-0,2153$ \\
\hline $\mathrm{N}^{-\mathrm{NO}_{3}^{-}}$ & $-0,21101$ & $-0,22349$ & 0,16867 \\
\hline${\mathrm{N}-\mathrm{NO}_{2}^{-}}^{-}$ & $-0,14651$ & 0,16708 & $-0,1043$ \\
\hline $\mathrm{N}-\mathrm{NH}_{4}^{+}$ & $-0,17952$ & $-0,27834$ & 0,11044 \\
\hline $\mathrm{P}-\mathrm{PO}_{4}^{3-}$ & $-0,18995$ & $-0,18632$ & 0,18293 \\
\hline Acid R. & 0,21424 & $-0,07597$ & 0,229 \\
\hline Carb. R. & $-0,00282$ & 0,00705 & 0,02748 \\
\hline Molasse & $-0,06385$ & 0,09617 & $-0,3798$ \\
\hline $\mathrm{N}-\mathrm{Q}$ & $-0,20911$ & 0,00924 & 0,30605 \\
\hline Mafic R. & 0,0148 & 0,07102 & $-0,12384$ \\
\hline Flow & $-0,0083$ & 0,17722 & 0,34558 \\
\hline Elevation & 0,21405 & $-0,25108$ & $-0,02306$ \\
\hline Slope & 0,19389 & $-0,09856$ & $-0,16763$ \\
\hline$B-b$ & 0,12518 & 0,00767 & $-0,31431$ \\
\hline$P-c$ & $-0,05444$ & 0,29276 & 0,22081 \\
\hline Sand & 0,10434 & 0,13615 & 0,26682 \\
\hline Silt-clay & $-0,19071$ & $-0,21766$ & $-0,04024$ \\
\hline \multicolumn{4}{|l|}{ Sampling site } \\
\hline 1 & 5,34779 & $-5,36712$ & $-0,16341$ \\
\hline 2 & 4,92655 & $-4,91897$ & 0,0064 \\
\hline 3 & 4,91101 & $-4,5553$ & $-0,27104$ \\
\hline 4 & 3,68304 & $-2,52845$ & 0,71636 \\
\hline 5 & 2,17561 & $-3,57254$ & $-1,30875$ \\
\hline 6 & 2,40209 & $-3,90383$ & $-0,21577$ \\
\hline 7 & 2,04176 & $-1,97775$ & 0,43617 \\
\hline 8 & 0,34946 & $-5,60268$ & 0,20254 \\
\hline 9 & 1,50406 & $-2,6017$ & 0,34837 \\
\hline 10 & 1,81819 & $-1,43466$ & 0,59199 \\
\hline 11 & 2,92401 & $-2,73055$ & $-2,16998$ \\
\hline 12 & 2,70315 & $-2,20494$ & $-0,68114$ \\
\hline 13 & 1,60202 & $-0,65267$ & 0,57941 \\
\hline 14 & 2,32811 & $-3,87837$ & $-2,13386$ \\
\hline 15 & 2,95252 & $-2,94307$ & $-1,75319$ \\
\hline 16 & 0,41792 & $-0,56581$ & $-0,11949$ \\
\hline
\end{tabular}


Table 5. A combination of French and Italian chemical quality classes for rivers (Cardoso et al., 2001; Decreto Legislativo, 1999) and a provisional classification of upper Aliakmon chemical quality based on NPM.

\begin{tabular}{|c|c|c|c|c|c|}
\hline & I & II & III & IV & $\mathbf{V}$ \\
\hline $\begin{array}{l}\mathrm{NO}_{\overline{3}}^{-} \\
\text {sites }\end{array}$ & $\frac{\mathbf{2}}{1,2,3,6,11,12,15}$ & $\begin{array}{c}\mathbf{1 0} \\
4,5,7,9,10,13,14,16\end{array}$ & $\begin{array}{c}\mathbf{2 5}-\mathbf{5 0} \\
8\end{array}$ & $\begin{array}{c}50 \text { - } 80 \\
-\end{array}$ & $\begin{array}{c}>80 \\
-\end{array}$ \\
\hline $\begin{array}{l}\mathrm{NO}_{32}^{-} \\
\text {sites }\end{array}$ & $\begin{array}{c}<\mathbf{0 . 3} \\
1,2,3,15\end{array}$ & $\begin{array}{c}<\mathbf{1 . 5} \\
4,6,10,12,13,14,16\end{array}$ & $\begin{array}{c}<\mathbf{5} \\
5,7,9,11\end{array}$ & $\begin{array}{c}<10 \\
-\end{array}$ & $\begin{array}{c}>\mathbf{1 0} \\
8\end{array}$ \\
\hline $\begin{array}{l}\mathbf{N H}_{4}^{+}{ }_{1} \\
\text { sites }\end{array}$ & $\begin{array}{l}\quad<0.1 \\
\text { all other sites }\end{array}$ & $\begin{array}{c}\mathbf{0 . 1} \mathbf{- 0 . 5} \\
6,9\end{array}$ & $\begin{array}{c}0.5-2 \\
-\end{array}$ & $\begin{array}{c}2-8 \\
8\end{array}$ & $\begin{array}{l}>8 \\
-\end{array}$ \\
\hline $\begin{array}{l}\mathbf{N H}_{42}^{+} \\
\text {sites }\end{array}$ & $\begin{array}{c}<\mathbf{0 . 0 3} \\
1,2,3,4,5,7,14,15\end{array}$ & $\begin{array}{c}<\mathbf{0 . 1} \\
10,11,12,13,16\end{array}$ & $\begin{array}{c}<\mathbf{0 . 5} \\
6,9\end{array}$ & $\begin{array}{c}<1.5 \\
-\end{array}$ & $\begin{array}{c}>1.5 \\
8\end{array}$ \\
\hline $\begin{array}{l}\mathbf{P O}_{4}^{3-}{ }_{1} \\
\text { sites }\end{array}$ & $\begin{array}{c}<\mathbf{0 . 2} \\
2,5,7,12\end{array}$ & $\begin{array}{c}\mathbf{0 . 2}-\mathbf{0 . 5} \\
\text { all other sites }\end{array}$ & $\begin{array}{c}0.5-1 \\
-\end{array}$ & $\begin{array}{c}1-2 \\
-\end{array}$ & $\begin{array}{l}>2 \\
-\end{array}$ \\
\hline $\begin{array}{r}\mathbf{O}_{21} \\
\text { sites }\end{array}$ & $\begin{array}{c}\quad>7 \\
\text { all other sites }\end{array}$ & $\begin{array}{c}7-5 \\
14\end{array}$ & $\begin{array}{c}5-3 \\
-\end{array}$ & $3-1$ & $\begin{array}{c}<\mathbf{1} \\
8\end{array}$ \\
\hline $\begin{array}{l}\text { NPM } \\
\text { sites }\end{array}$ & $\begin{array}{c}<\mathbf{0 . 5} \\
1,2,3,11,12,15\end{array}$ & $\begin{array}{c}<\mathbf{1} \\
4,5,6,10,13,14,16\end{array}$ & $\begin{array}{l}<\mathbf{3} \\
7,9\end{array}$ & $\begin{array}{l}<5 \\
-\end{array}$ & $\begin{array}{c}>6 \\
8\end{array}$ \\
\hline
\end{tabular}

1: French System, 2: Italian System

\subsection{Hydrochemical quality assessment and classification}

Regarding hydrochemical quality, in absence of an official Greek classification system, a combination of the French and Italian one was applied. In addition, a first attempt for a hydrochemical classification based on NPM is presented. Within classification systems five quality classes (Q.C.) are distinguished, according to the WFD, i.e. high, good, moderate, poor and bad (Table 5). According to the French system, as far as nitrates are concerned, the sites are almost equally distributed between Q.C. I and II, while only one site (8) belongs to Q.C. III. According to the Italian system the sites are distributed between Q.C. I and III, with the majority of them lying in Q.C. II, while site 8 belongs to Q.C. V. Concerning ammonium, according to the French system, the majority of the sites are classified under Q.C. I, two sites $(6,9)$ belong to Q.C. II and one site (8) is classified as IV. According to the Italian system, the main part of the sites is grouped within Q.C. I and II, while sites 6, 9 and 8 are shifted in Q.C. III and V respectively. In case of phosphate, the sites fall within categories I and II, while for dissolved oxygen, only two sites fall outside Q.C. I (st. 14: II and st. 8: IV).

According to a classification based on NPM, the upstream Aliakmon main stem and tributary sites (st. 1, 2 and st. 3, 11, 12, 15 respectively) could be hydrochemically classified as "reference" sites. Two Aliakmon mainstem sites (st. 7, 9), which are affected by municipal and other wastes, are classified as "moderate", the Kastoria Lake outflow (st. 8) as "bad", while the other sites present "good" chemical quality.

\subsection{Ecological quality assessment}

As mentioned previously (chapter 1), biological, hydromorphological and chemical/physicochemical elements are required for the ecological assessment. A rivers' ecological quality has to be assessed by studying a series of biological elements, such as aquatic flora, benthic invertebrate fauna and fish fauna.

Benthic macroinvertebrates are regarded as the most suitable quality element in identifying the impact of different types of pollution. In addition, many methods of data analysis have been developed (Resh et al., 1996).

According to the WFD (Annex V, 1.4.2.), ecological assessment and classification is made on the basis of biological and physico-chemical results. A methodology for the assessment of the ecological quality of running waters based on benthic macroinvertebtares and chemical elements is pre- 


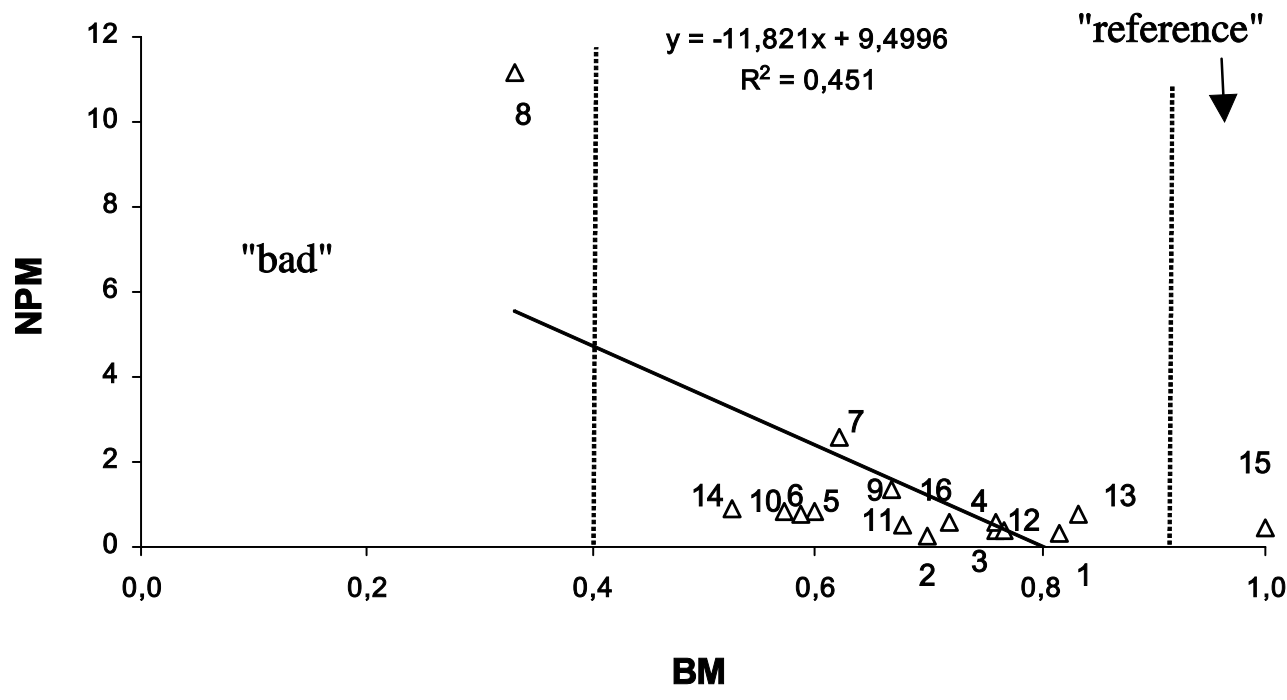

Figure 2. Correlation between the Nutrient Pollution Metric and the macroinvertebrate Biotic Metric and ecological classification into three quality classes

sented. An appropriate biotic metric for identifying nutrient impact should be correlated to nutrient concentrations. Since NPM is a measure of the sum of nutrients in river water, it should be correlated with the suitable biotic index. For that purpose a series of metrics (BMWP, ASPT, Spanish BMWP and ASPT, Extended Biotic Index, Belgian Biotic Index, Danish Stream Fauna Index, and several Saprobic Indices) was applied. Best correlation showed the Spanish ASPT, which was slightly modified (see chapter $3)$. The reason for this modification was that the Ecological Quality Ratio (EQR), i.e. the ratio between the observed biological status and the reference state, should be close to the unit for a site with similar status to the reference condition, while the quality of a site approaching zero should be in worst condition (Cardoso et al., 2001).

In the following, an ecological quality assessment methodology is presented, that is based on benthic macroinvertebrates and embodies chemical quality (nutrient concentrations). As already mentioned (chapter 4.1), BM and NPM are correlated with each other. BM and NPM correlations to chloride are also apparent (Table 4, Annex I). Municipal wastewaters are rich in chloride. Since evaporites are not present in the catchment area, BM and NPM seem to be suitable for detecting organic pollution. Fig. 2 shows the regression between BM - NPM.

According to Fig. 2, site 8 could be safely termed ecologically as a site in "bad" condition, since it presents the lowest biological and chemical quality values. Site 15 shows the highest biological quality compared to the other sites. Concerning its chemical quality however, it is slightly more polluted than sites $1,2,3$ and 12 . This slightly higher pollution is mainly caused by its higher phosphate concentration (Table 3), which could originate from vegetation leaching (Bond, 1979). Nevertheless, since its BM value is by far higher than that of the other sites, site 15 could be classified as a "high" quality site with no or minor (depending on the origin of phosphate) disturbance (WFD). For the intermediate sites ("good" to "poor"), the ecological quality classification could only be based on BM, since BM and NPM correlations are not sufficient. The insufficient correlation between BM and NPM for these sites is attributed to their vast substrate and habitat composition differences. In fact, substrate and habitat composition primarily determine the type of aquatic communities (Knoben et al., 1995). This situation is also provided by our results (see chapter 4.1). In addition, not all habitats present were equally sampled (see chapter 2 ). In the 
framework of the AQEM project ("The Development and Testing of an Integrated Assessment System for the Ecological Quality of Streams and Rivers throughout Europe using Benthic Macroinvertebrates"), a river-type specific BM and an ecological quality classification system is under development. The index is based on the fauna found in "reference" sites and the faunistic deviation in degraded sites. A 45-site sampling network was used, covering three distinct river types. The selection of sites was done very carefully, so that selected sites would present, more or less, similar habitat composition. In addition, a standardised multihabitat sampling procedure was applied.

\section{CONCLUSIONS}

Catchment geology and morphology (elevation and slope) affect baseflow contribution in river flow, chemical weathering, and erosion and hence riverine solute concentrations and river substrate. As a result, river parts situated at lowland (neogene-quaternary) formations show high mineralization and their river bed is covered by low grain size material. In addition, streams, located in subcatchments, where mafic formations dominate, show high concentrations of silicate and magnesium. River substrate, in turn, governs taxa distribution and abundance. In particular, sites with high pebble-cobble percentage show high biological quality, whereas silty-clayey sites present low biological quality. The latter relation is not only due to habitat preferences of macroinvertebrates, but also to the fact that silty-clayey sites are situated at lowland river parts, that are more polluted. In these river parts decomposition processes prevail and chloride concentrations are elevated (due to waste water inputs) and thus they present degradation in chemical, and biological quality. A characteristic example for this situation is the Lake Kastoria outflow. In contrast, at the lowland Aliakmon mainstem sites, photosynthetic activities dominate. According to a preliminary hydrochemical classification of running waters, based on a new Nutrient Pollution Metric (NPM), thirteen sites are classified within "high" and "good" quality classes, two polluted Aliakmon main-stem sites belong to "poor" status, while the outflow of Kastoria Lake is termed as a "bad" one. A methodology for the assessment of the ecological quality of running waters based on benthic macroinvertebtares and chemical quality, shows that the most appropriate biological metric (BM) is the Spanish-ASPT. This metric was slightly modified in order to vary between 0 and 1 , according to the demands of the WFD. Using BM and NPM it was possible to separate ecologically a "reference" and a "bad" site from all the other sites, which range between "good" and "poor" status. The low BM-NPM correlation at the sites with intermediate quality is attributed to the fact that their biological quality is mainly controlled by habitat preferences that "mask" water quality differences. Hence, in order to compare sites, with confidence that differences obtained from macroinvertebrate data, result from water quality, it is recommended to apply habitat-specific sampling. Therefore, any future research work should carry out specific multihabitat sampling and keep and investigate the replicates separately. Finally, a national project is urgently needed in order to define river type specific "reference" conditions and develop a Greek Biotic Metric, based on an extended network of sampling sites.

\section{REFERENCES}

Alba-Tercedor, J. and Sanchez-Ortega, A. (1988), Un metodo rapido y simple para evaluar la calidad biologica de las aguas corrientes basado en el de Hellawell (1978), LIMNETICA, 4, 51-56.

Armitage, P.D., Moss, D., Wright, J.F. and Furse, M.T. (1983), The performance of a new biological water quality score system based on macroinvertebrates over a wide range of unpolluted running- water sites, WAT. RES., 17, 333-347.

Bond, H.W. (1979),Nutrient concentration patterns in a stream draining a montane ecosystem in Utah, ECOLOGY, 60, 1184-1196.

Cardoso, A.C., Duchemin, J., Magoarou, P. and Premazzi, G. (2001), Criteria for the identification of freshwater subject to eutrophication. Their use for the implementation of the "Nitrates" and Urban Waste Water Directives. EUR 19810 EN, EU - JRC, 87.

Decreto Legislativo, n. 152 (1999), Disposizioni sulla tutela delle acque dall'inquinamento e recepimento della direttiva 91/271/CEE concernete il trattamento delle acque reflue urbane e della direttiva 91/676/CEE 
relative alla protezione delle acque dall'inquinamento provocato dai nitrati provenienti da fonti agricole. Supplemento Ordinario n. 101/L alla Gazzetta Ufficiale 29 maggio 1999, n. 124.

Hem, J.D. (1970), Study and interpretation of the chemical characteristics of natural water, U.S. GEOLOGICAL SURVEY WATER SUPPLY PAPER, 1473, 363.

Knoben, R.A.E., Roos, C. and Van Oirschot, M.C.M. (1995), Task Force on Monitoring \& Assessment. Biological Assessment Methods for Watercourses, UN/ECE, 3, 86.

Malikopoulos, S.K. (1957), Collection of data on the hydraulic forces in Greece, Report of the Ministry of Public Works, Athens.

Petts, G. and Calow, P. (eds.), (1996), River flows and channel forms, Blackwell Science.

Resh, V.H., Myers, M.J. and Hannaford, M.J. (1996), Macroinvertebrates as biotic indicators of Environmental Quality, In: Methods in Stream Ecology, Hauer, F.R. and Lamberti, G.A. (eds.), Academic Press.

Skoulikidis, N.Th. (1991), Parameters influencing the Chemistry and Pollution of River Water - Characteristic Example the River Nestos, Greece, In: $2^{\text {nd }}$ Conf. on Environmental Science and Technology, Lekkas, Th. (ed.), Molyvos, Lesvos, Greece.

Skoulikidis N.Th. (1993). Significance evaluation of factors controlling river water composition. ENVIRONMENTAL GEOLOGY, 22, 178-185.

Tolkamp, H.H. (1984), Biological assessment of water quality in running water using macroinvertebrates: a case study for Limburg, THE NETHERLANDS, WAT. SCI. TECHN., 17, 867-878.

Ward, J.V. (1992), Aquatic Insect Ecology. 1. Biology and Habitat. John Wiley \& Sons, Inc., New York, Chichester, Brisbane, Toronto, Singapore, 438.

Water Framework Directive (2000), Directive 2000/60/EC of the European Parliament and of the Council of 23 October 2000 establishing a framework for Community action in the field of water policy. 


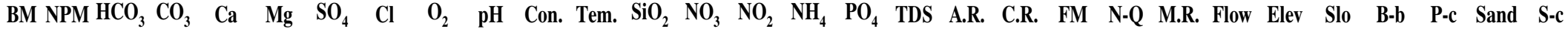
BM 1,0

NPM $-0,7 \quad 1,0$

$\mathrm{HCO}_{3}-0,6 \quad 0,5 \quad 1,0$

$\mathrm{CO}_{3} \quad 0,2 \quad-0,1 \quad 0,1 \quad 1,0$

$\begin{array}{lllllll}\text { Ca } & -0,4 & 0,4 & 0,8 & 0,4 & 1,0\end{array}$

$\begin{array}{lllllll}\text { Mg } & -0,4 & 0,1 & 0,8 & 0,1 & 0,6 & 1,0\end{array}$

$\begin{array}{llllllll}\mathbf{S O}_{4} & -0,5 & 0,3 & 0,8 & -0,2 & 0,7 & 0,7 & 1,0\end{array}$

$\begin{array}{lllllllll}\text { Cl } & -0,8 & 0,8 & 0,7 & -0,3 & 0,3 & 0,4 & 0,5 & 1,0\end{array}$

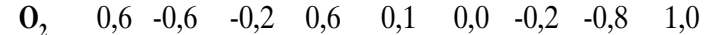

$\begin{array}{llllllllllll}\mathbf{p H} & 0,3 & -0,4 & 0,4 & 0,6 & 0,5 & 0,6 & 0,3 & -0,4 & 0,7 & 1,0\end{array}$

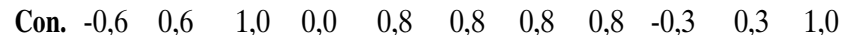

$\begin{array}{llllllllllll}\text { Tem. }-0,3 & 0,3 & 0,6 & 0,3 & 0,7 & 0,6 & 0,3 & 0,3 & 0,2 & 0,6 & 0,6 & 1,0\end{array}$

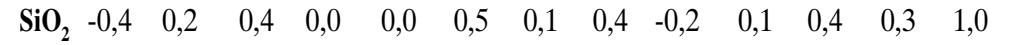

$\begin{array}{lllllllllllllll}\mathrm{NO}_{3} & -0,7 & 1,0 & 0,5 & -0,1 & 0,5 & 0,2 & 0,4 & 0,8 & -0,6 & -0,4 & 0,6 & 0,3 & 0,1 & 1,0\end{array}$

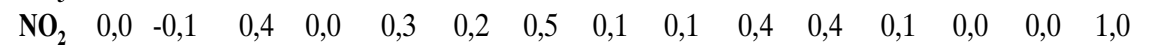

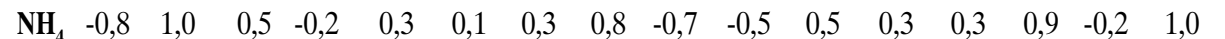

$\begin{array}{llllllllllllllllll}\mathbf{P O}_{4} & -0,6 & 0,9 & 0,4 & 0,2 & 0,4 & 0,1 & 0,3 & 0,7 & -0,5 & -0,3 & 0,5 & 0,2 & 0,1 & 0,9 & -0,1 & 0,8 & 1,0\end{array}$

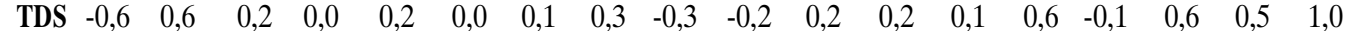

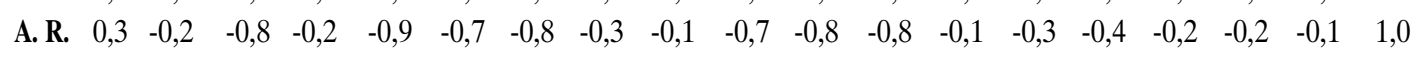

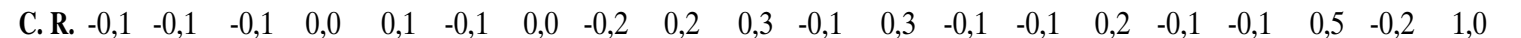

$\begin{array}{llllllllllllllllllllllll}\text { F-M } & 0,0 & -0,2 & 0,4 & -0,2 & 0,4 & 0,4 & 0,6 & 0,2 & -0,1 & 0,3 & 0,4 & 0,1 & -0,1 & -0,2 & 0,4 & -0,2 & -0,2 & -0,4 & -0,5 & -0,2 & 1,0 & & \\ \end{array}$

$\begin{array}{lllllllllllllllllllllllll}\mathbf{N}-\mathbf{Q} & -0,3 & 0,7 & 0,3 & 0,2 & 0,5 & 0,1 & 0,3 & 0,4 & -0,1 & -0,1 & 0,4 & 0,3 & -0,2 & 0,8 & 0,0 & 0,6 & 0,7 & 0,3 & -0,3 & -0,2 & -0,3 & 1,0 & *\end{array}$

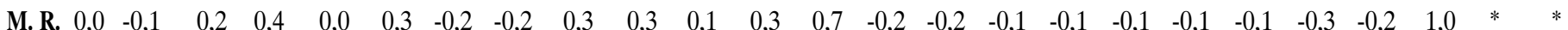

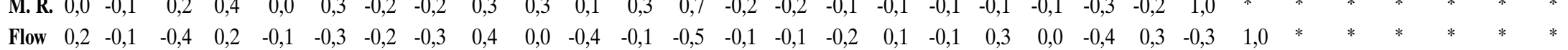

$\begin{array}{llllllllllllllllllllllllllllllllllll}\text { Elev. } & 0,1 & -0,2 & -0,6 & -0,3 & -0,7 & -0,7 & -0,5 & -0,2 & -0,3 & -0,6 & -0,6 & -0,6 & 0,1 & -0,2 & -0,2 & -0,1 & -0,2 & 0,0 & 0,8 & 0,0 & -0,3 & -0,5 & 0,0 & 0,0 & 1,0 & * & * & * & * & *\end{array}$

$\begin{array}{lllllllllllllllllllllllllllllllllllllllll}\text { Slope } & 0,2 & -0,3 & -0,5 & -0,2 & -0,8 & -0,3 & -0,5 & -0,2 & -0,1 & -0,4 & -0,5 & -0,5 & 0,4 & -0,4 & -0,2 & -0,2 & -0,3 & -0,3 & 0,7 & -0,2 & -0,2 & -0,5 & 0,3 & -0,1 & 0,8 & 1,0 & * & * & * & *\end{array}$

$\begin{array}{lllllllllllllllllllllllllllllllll}\mathbf{B}-\mathbf{b} & 0,3 & -0,4 & -0,4 & -0,1 & -0,5 & -0,2 & -0,3 & -0,2 & -0,1 & -0,2 & -0,4 & -0,4 & 0,0 & -0,5 & -0,2 & -0,3 & -0,3 & -0,4 & 0,3 & -0,3 & 0,4 & -0,6 & 0,1 & -0,3 & 0,5 & 0,6 & 1,0 & * & * & *\end{array}$

$\begin{array}{llllllllllllllllllllllllllllllllll}\mathbf{P}-\mathbf{c} & 0,3 & -0,2 & -0,1 & 0,5 & 0,1 & 0,1 & -0,2 & -0,3 & 0,6 & 0,4 & -0,1 & 0,3 & -0,1 & -0,2 & -0,2 & -0,3 & -0,1 & -0,4 & 0,0 & -0,1 & -0,4 & 0,3 & 0,2 & 0,5 & -0,4 & -0,2 & -0,5 & 1,0 & * & *\end{array}$ $\begin{array}{llllllllllllllllllllllllllllllllllll}\text { Sand } & 0,6 & -0,3 & -0,6 & 0,0 & -0,5 & -0,6 & -0,6 & -0,4 & 0,2 & -0,2 & -0,6 & -0,5 & -0,2 & -0,3 & -0,1 & -0,3 & -0,3 & -0,3 & 0,6 & -0,3 & -0,4 & 0,0 & 0,0 & 0,3 & 0,2 & 0,2 & 0,0 & 0,3 & 1,0 & * \\ \text { S-C } & -0,7 & 0,6 & 0,5 & -0,4 & 0,5 & 0,2 & 0,7 & 0,6 & -0,5 & -0,1 & 0,6 & 0,2 & 0,2 & 0,7 & 0,4 & 0,6 & 0,5 & 0,7 & -0,4 & 0,4 & 0,1 & 0,3 & -0,3 & -0,3 & -0,1 & -0,4 & -0,4 & -0,6 & -0,5 & 1,0\end{array}$

Con.: conductivity, Temp. temperature, TDS: total dissolved solids, A.R.: acid rocks, C.R.: carbonate rocks, F-M: flysch-molasse, N-Q: neogene-quaternary, M.R.: mafic rocks,

Elev.: elevation, B-b: bedrock-boulders, P-c: pebbles-cobbles, S-C: silt-clay 